\title{
原発性膀胼肉腫の 3 例と本邦報告例の検討
}

\begin{tabular}{|c|c|c|c|}
\hline & 小 & $\begin{array}{l}\text { 林 } \\
\text { 林 }\end{array}$ & 峰 \\
\hline 名古屋大学医学部泌尿器科教室 & 鈴 & 木 & 靖 \\
\hline (主任：三矢英輔教授) & 村 & 瀬 & 達 \\
\hline & 三 & 宅 & 弘 \\
\hline & 三 & 矢 & 英 \\
\hline $\begin{array}{c}\text { 名古屋大学附属病院検查部門 } \\
(\text { (主任:牛島 有 })\end{array}$ & 中 & 島 & 伸 \\
\hline $\begin{array}{c}\text { 名古屋大学医学部医動物学教室 } \\
\text { (主任 : 熊田信夫) }\end{array}$ & 越 & 川 & \\
\hline
\end{tabular}

\section{PRIMARY BLADDER SARCOMA THREE CASE REPORTS AND REVIEW OF THE JAPANESE LITERATURE}

Mineo Kobayashi, Osamu Kobayashi, Haruo Suzuki, Tatsuro Murase,

Khoji Miyake and Hideo Mitsuya

Department of Urology, Nagoya University School of Medicine, Nagoya 466

(Director: Prof. H. Mitsuya)

Nobuo Nakashima

Section of Clinical Pathology, Nagoya University Hospital, Nagoya 466

(Director: Prof. H. Ushijima)

Takashi Koshikawa

Department of Medical Zoology, Nagoya University School of Medicine, Nagoya 466

(Director: N. Kumada)

Two cases of bladder rhabdomyosarcoma and one case of bladder leiomyosarcoma are reported. One case of rhabdomyosarcoma, 5-year-old boy, has been free of tumor for 91 months after total cystectomy and the other case, 3-year-old boy, died 15 months after total cystectomy followed by radiotherapy and chemotherapy (Actinomycin D). A case of leiomyosarcoma, 26-year-old female, has been free of tumor for 6 months after total cystectomy followed by radiotherapy and chemotherapy (Actinomycin D, Vincristine).

One hundred thirty cases of bladder sarcoma during the past 20 years (1960-1980) were reviwed in the Japanese literature to which 3 new cases were added. We have made a discussion on age distribution, sex, treatment and postoperative course.

要旨： 2 例の小児膀脂横紋筋肉腫と, 1 例の成人膀胱平滑筋肉腫を経験した。横紋笳肉腫の 1 例は 5 歳 男子で膀胱全摘出術後 7 年 7 力月現在健在であり,他の 1 例は 3 歳男子で膀胱全摘出術後に放射線療法, Actinomycin D 投与を施行したが，術後 1 年 3 カ月目に死亡した。平滑筋肉腫例は 26 歳の女性で膀胼全 摘出術後に放射線療法及び Vincristine, Actinomycin D 投与を施行し, 術後 6 力月の現在健在である. 1960年から1980年の間の本邦で報告された膀胼肉腫130例と我々の 3 例を加光, 集計するとともに, 膀羘 肉腫の発生年齢, 性, 予後, 治療につき考察した。

緒 言

原発性膀胼肉腫は比較的まれな疾患である。我々は,
膀胖原発の小児横紋筋肉腫 2 例, 成人平滑筋肉腫 1 例 を経験したので報告するとともに，1960年から1980年 
の間に本邦に扮いて報告された130例の膀胱肉腫を集 計し，横紋筋肉腫と平滑筋肉腫の対比を中心に若干の 考察を加える。

\section{症例}

1. 太淳 $\bigcirc 5$ 歳（昭和 43 年 6 月 25 日生）男 初診：昭和 49 年 3 月 19 日

主訴：排尿困難，肉眼的血尿，尿失禁

家族歴：特記すべきことなし。

既往歴：特記すべさことなく，出産発育は正常。

現病歴：昭和 48 年 12 月末，急に排尿困難，肉眼的血 尿出現，近医にて膀胱炎の治療をらけ一時症状軽快し た。翌年 1 月上り再度血尿，尿失禁，腹痛，発熱をさ たし，近医にて数回導尿らけた。同年 3 月名鉄病院 を訪れ，名古屋大学泌尿器科を紹介され入院となつた。

現症：身長 $110 \mathrm{~cm}$, 体重 $16.5 \mathrm{~kg}$, 体格中等度, 栄養良 好で表在リンパ節解知せず，胸部異常なく，腹部やや 膨隆するも，抵抗，圧痛認めず，腫瘍も触知せず。

入院時検査所見：赤沈 1 時間值 $65 \mathrm{~mm} ， 2$ 時間值 103 $\mathrm{mm}$ と促進している以外, 血算, 血液生化学, 心電㘠, 胸部レ線に異常を認めず.尿沈查にて赤血球 8-10個/ 1 視野，白血球30 35個/ 1 視野認め，尿培養て Pseudomonas aeruginosa が $5 \times 10^{5} / \mathrm{ml}$ 検出された。

レ線所見；I. V. P. 飞て両側の朝度水腎水尿管を認 め，C. U. G. にて膀胼顏部に陰影欠損を認めた。

入院経過：以上の所見より悪性腫瘍を疑い，全麻下 に膀脱鏡，直腸双手診，膀胱高位切開に上る生検を施 行した。膀胼鏡的には，内尿道口全体の膨隆を認める も表面は平担であった。双手診では超鵎卵大の腫瘤を 触知した。高位切開にて，膀胱内を直視下に見ると内 尿道口周囲に, ぶどら房状腫瘍を認め, 一部切除し生 検とした。この切除組織の病理検査では悪性像は認め られなからたが，臨床的に悪性腫痬が強く疑われ，同 年 4 月26日再度全麻下に膀胱を開さ，術中迅速凍結標 本を提出し, 横紋筋肉腫の病理診断を得たので, 膀胱 前立腺全摘出術，回腸導管造設術を施行した。

手術所見：腫瘍の膀胱外への浸潤は認めず，膀胱前 立腺剝離は容易であつた。腹腔内には異常を認めず, 回腸導管による尿路変向を施行した。摘出膀脱は超鶏 卵大で，内尿道口を中心に腫瘍を認めた。

病理組織所見：幼若な筋芽細胞が浮腫状の間質内に 疎に配列増生し，上く分化した腫瘍細胞では胞体が赤 く，横紋を認めた。横紋筋肉腫の像であつた。畽瘍は 前立腺内字で浸潤していたが，浆膜面への浸潤は認め なからた (Fig. 1).
Fig. 1 症例 1 の横紋筋肉腫組織像

$\mathrm{A}$ ：幼若な筋芽細胞が浮腫状の間質に不規則に増生 する.（H.E. 染色，50倍)

B：よく分化した腫瘍細胞では横紋を認める(H.E. 染色, 200倍

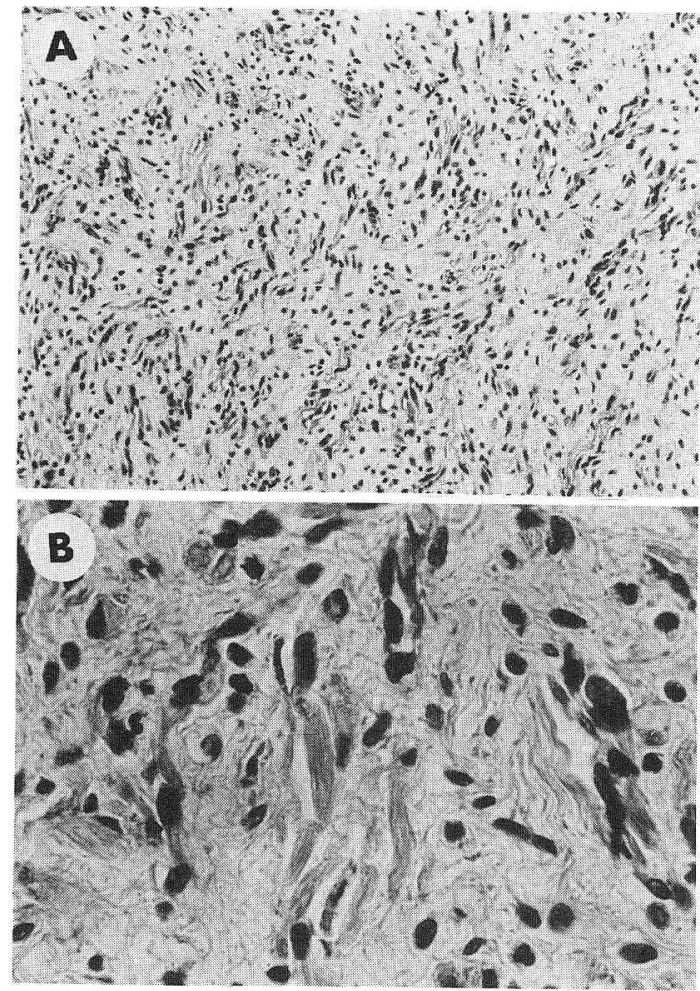

術後経過：良好で入院 2 力月後に退院した。術後の 化学療法, 放射線療法は施行しなからた。退院後元気 に外来通院して和り, 術後 7 年 7 カ月たつた現在まつ たく再発の徵候なく，治癒せしめたと考党ている。

2. 加○剛 3 歳（昭和47年 7 月 24 日生）男 初診：昭和 51 年 5 月 26 日

主訴：頻尿 肉眼的血尿 尿失禁

家族歴：特記すべきことなし

既往歴：特記すべきことなく，出産発育は正常。

現病歴：昭和 51 年 2 月末に無症候性血尿出現。その 後頻度，尿失禁も出現し，近医にて膀胱炎として治療 をうけるも変化なく, 名古屋大学泌尿器科を訪れ，5 月26日入院した。

現症：体重 $13.2 \mathrm{~kg}$, 身長 $95 \mathrm{~cm}$, 体格中等度で栄養良 好。表在リンパ節触知せず胸部は正常。腹部は平担軟 で圧痛．抵抗認めず，腫瘤も触知せず。

入院時検查所見：赤沈，血算，生化学，心電図，胸 
Fig. 2 症例 2 の横紋筋肉腫組織像

A：幼若筋芽細胞が散在性にあるいは束状に配列し 増生する。(H.E. 染色, 50倍)

B：腫瘍細胞胞体に横紋を認める(H.E 染色, 200倍)

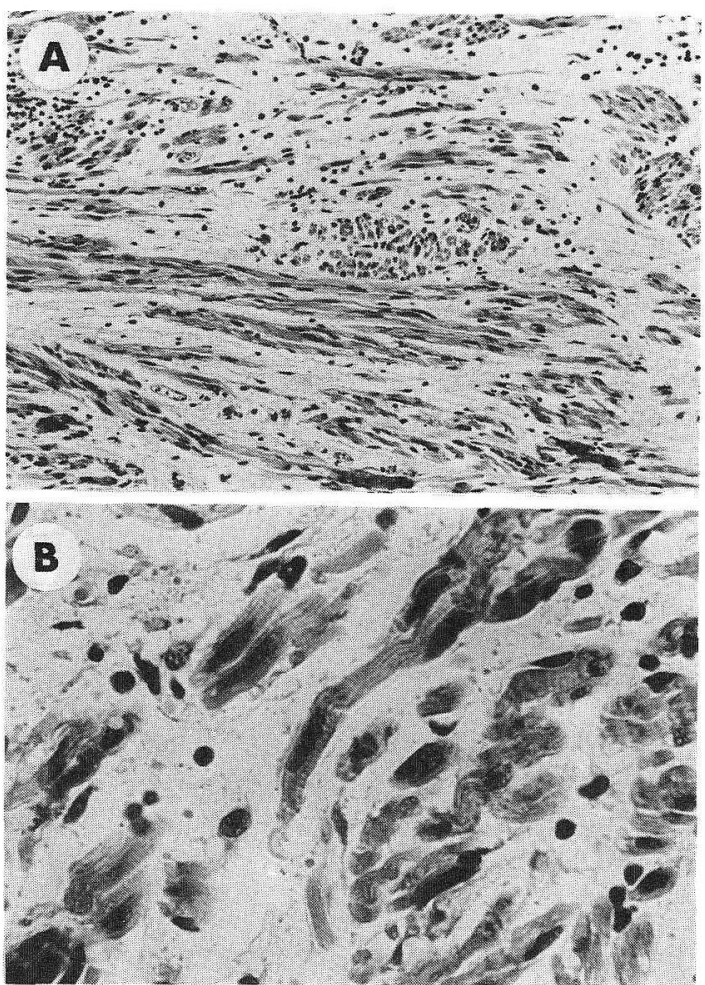

Fig. 3 症例 3 の平滑筋肉腫組織像

A：長紡錘形の腫瘍細胞が束をなし，不規則に交錯 して増生する。(H.E. 染色, 50倍)

$\mathrm{B}$ : 腫瘍細胞は細線維状の胞体, 長円形の大型の核, 明瞭な核小体を持つ. mitosisは多くないが認める。 (H.E 染色, 200倍)

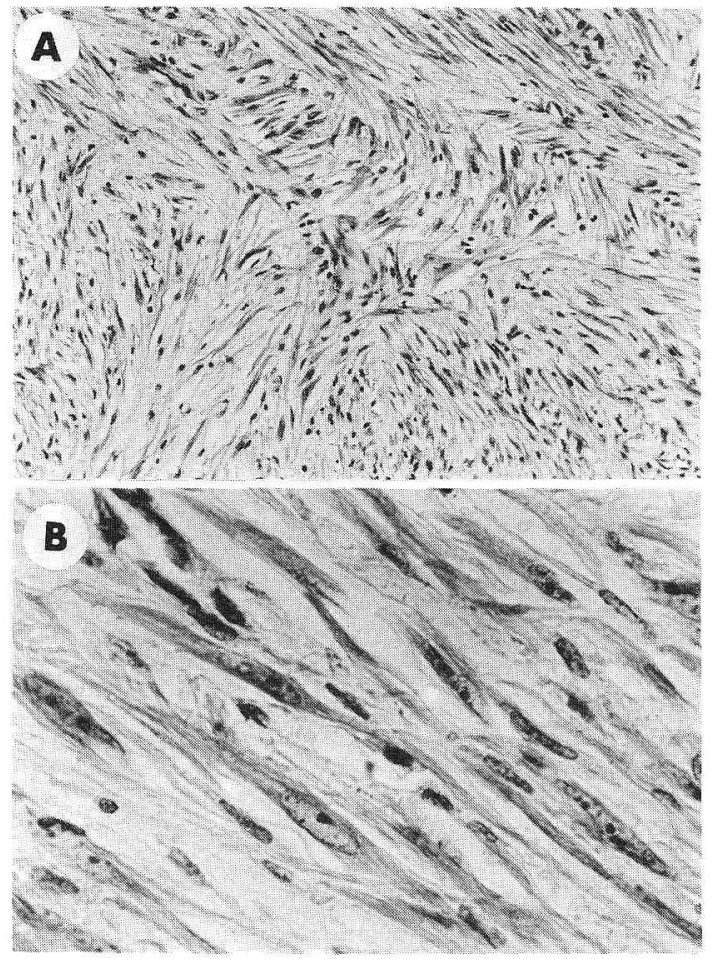

病理組織所見；Rhabdomyoblast が散在性にある いは束状に配列増生し，一部は末分化腫瘍細胞に強い 異形点認めた。横紋筋肉腫 embryonal typeの像であ つた (Fig. 2).

術後経過：術後10日目より Cobalt 60 にて腹壁より 1 回 200rads で合計2,600rads, 会陰部より 1 回200 rads で合計 $2,600 \mathrm{rads}$, 総量4,800rads 在照射した。同 年 7 月 15 日退院し外来通院していたが，同年12月中旬 より下腹部に腫瘤を触知するようになり, 下痢, 体重 減少も出現し，12月28日再入院となつた。入院後補液 とともにActinomycin D 0.25mg/dayを連日 3 日間 投与後, Cobalt 60 にて膀胱部入総量2,640rads 再照射 した。これにより腹部腫瘤は触知しなくなり入院 3 ケ 月後に退院した。しかし昭和5 2 年 5 月より再度腫瘍の 再発登認め, 前回と同しくActinomycin D 及び放射線 療法至試みたが，同年 9 月25日肺転移による乎吸困難 にて死亡した。術後 1 年 3 カ月であつた。 
Fig. 4 症例 2 の排尿時膀胱尿道造影 膀胱䅡部から前立腺部尿道欠損を認める。

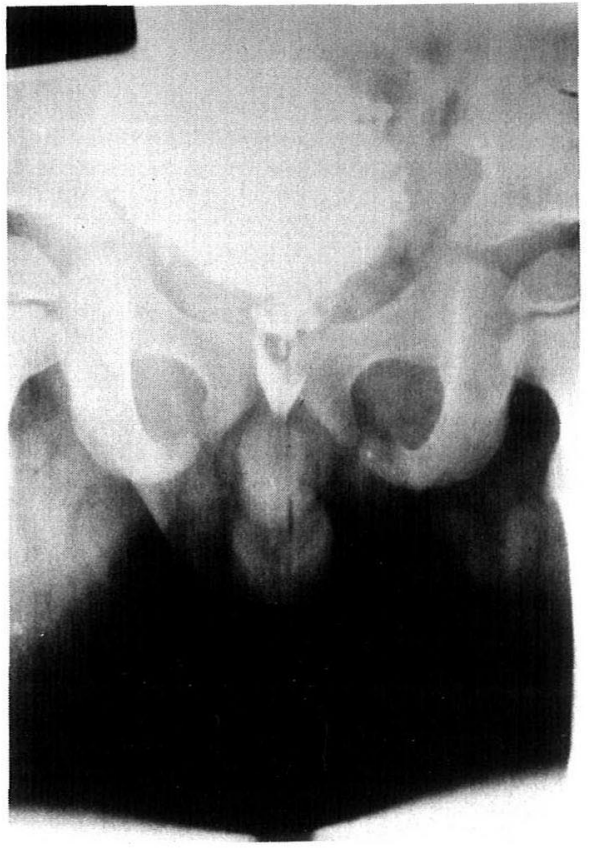

3. 服 $\bigcirc$ 由 $\bigcirc$ 子, 26 歳 (昭和 30 年 5 月 5 日生), 女, 会社事務員

初診；昭和 56 年 5 月 16 日

主訴; 肉眼的血尿, 排尿痛, 頻尿

家族歴；特記すべきことなし。

既往歴：6 歳時虫垂切除術をらけた。

現病歴; 昭和 56 年 4 月初旬上り, 排尿痛, 頻尿出現 し，近医にて膀胱炎をとして治療をうけた。5月中旬 再度, 肉眼的血尿, 排尿痛, 頻尿をさたし名古屋大学 泌尿器科を受診し，同年 6 月 5 日入院した。

現症：体格中等度で栄養良好。表在リンパ節は触知 せず，胸部は異常なく，腹部は右下腹部に手術瘢痕が あり，下腹部に压痛を認めたが，腫瘤は触知しなかつ た。

入院時検査所見：赤沈 1 時間值 $64 \mathrm{~mm}, 2$ 時間值 94 $\mathrm{mm}$ と促進, 血算で赤血球数 $366 \times 10^{4}$, 白血球数 8,100 , Hb $11.1 \mathrm{~g} / \mathrm{dl}, \mathrm{Ht} 31.9 \%$ と軽度貧血を認めたが，血液 像, 血液生化学, 心電図, 胸部レ線, 肝シンチグラム に異常を認めず。尿沈椬では赤血球多数, 白血球70-80 個/視野，扇平上皮 $8-10$ 個/視野認め, 尿培養にて Staphylococcus epidermidis が $10^{3} / \mathrm{ml}$ が検出された. 膀胱鏡所見：膀胱容量 $100 \mathrm{ml}$, 膀胱頚部より前壁に
Fig. 5 症例 3 の膀胱二重造影（腹臥位）

膀胱䅡部から前壁にかけ表面不整な腫瘍陰影を認め る。

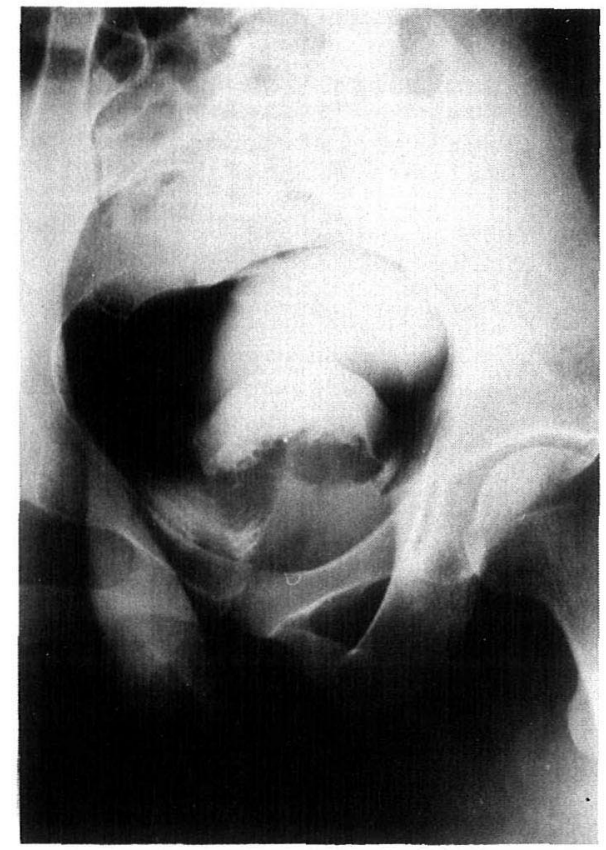

Fig. 6 症例 3 の CT 像（膀胱内に空気 $100 \mathrm{ml}$ 注入） 膀胱内腔へ突出した腫湯像を認める.

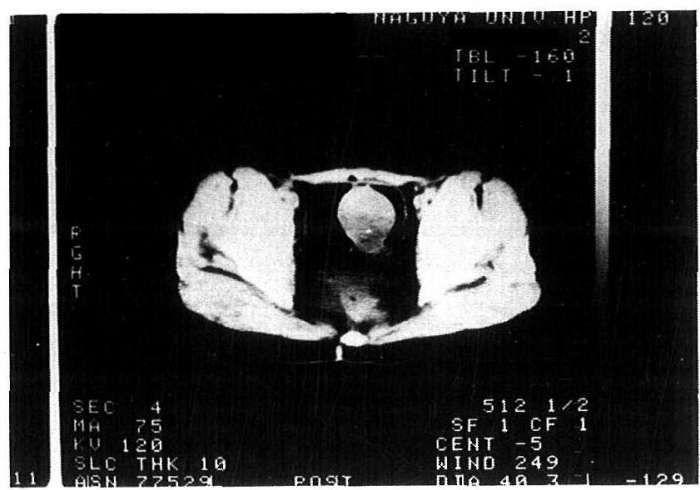

かけて, 半球状の腫瘤突出を認めた。粘膜面は浮腫状 であつた。

レ線所見；I，V．P. で上部尿路は異常ないが膀胼像 にて膀胼頝部の陰影欠損を認め, 膀胱造影では, 腹卧 位にて膀胱頝部から前壁に表面不整の腫瘍陰影を認め た (Fig. 5).

C. T. 所見：膀脱内人大きく突出した腫瘍像を認め た (Fig. 6). 
超音波断層所見：腹壁正中よりの矢状面での断層像 にて膀胱全壁に腫瘍エコー像を認めた（Fig. 7).

同年 6 月16日経尿道的膀胱生検を施行し, Myogenic sarcoma の病理診断を得たので同年 7 月 2 日全麻下に膀脱尿道全摘出術，骨盤リンパ節廓清術及 び回腸導管造設術を施行した。

手術所見；：膀胼は頝部に腫瘤を触知するも膀胱外 への浸潤は認めず，膀胼尿道の剥離摘出は容易であつ た，腹腔内には異常を認めず，左総腸骨リンパ節，左 内腸骨リンパ節の腫大を認めた。腹部大動脈分岐部よ り，内外腸骨動脈周囲，閉鎖リンパ節，正中仙骨リン パ節の廓清をおこなつた。尿路変向は回腸導管造設を 施行した。摘出膀腃は $170 \mathrm{~g}$, 腫瘍は膀胱顏部より前壁 にいたり，膀胱内腔へ発育突出し，大きさ $4 \times 5 \times 6$ cmであつた。

病理組織所見：膀胱粘膜下全層を腫瘍が占め, エオ ジン好性長紡鍾状の腫瘍細胞が束状に増生し，核は長 円形で型は軽度であるが細胞の大小不同，Mitosis 少数認めた。平滑筇肉腫の像であつた。廓清リンパ節 には腫瘍細胞を認めなかつた（Fig. 3).

術後経過: 術後 4 週目上り化学療法及び放射線療法 を開始した。化学療法はActinomycin D 1 日0.4mg を 5 日間連日, Vincristine $1 \mathrm{mg}$ 週 1 回を 4 週, 経静脈 投与を 1 クールとして始めた。投与 3 週目に，悪心， 発熱, 手足のしびれ感が強くなり, Vincristine 3 回投 与で中止した。放射線療法は Linac にて対向 2 門で 1 日180rads を膀胱部へ照射した。総量3,080rads の時点 で，放射線性腸炎，不完全イレウスを抗こし，照射を 中止した，併用療法中止後副作用怯消失したが，患者 の強い希望で昭和56年 9 月 19 日退院した。現在外来通 院中で, 術後 6 カ月目で再発の微候はまつたく認めて いない。

\section{本邦症例の統計および考察}

原発性膀脱肉腫は稀な腫瘍であり，全膀胱腫瘍の内 に占める割合は $0.21 \%$ から1.84\%といわれる(1223)45). 近年本邦での報告も増加して和り，我々が集計し光た かぎりでは1960年から1980年の間に膀胱肉腫報告例は 130例であつた (Table 1)。今回報告した我々の 3 例を 加え133例を集計し, 主に横絞筋肉腫と平滑笳肉腫を対 比しながら，その発生年齢，症状，部位，予後，治療 の相違を考察する。

\section{1. 組織学的分類}

肉腫は一つの腫晹の中に多くの異なる組織又は細胞 形態をとることが多く，その病理組織診断では種々の
Fig. 7 症例 3 の超音波断層像（腹壁正中より矢状面 での断層)

膀胱前壁に腫瘍壁のエコー像を認める.

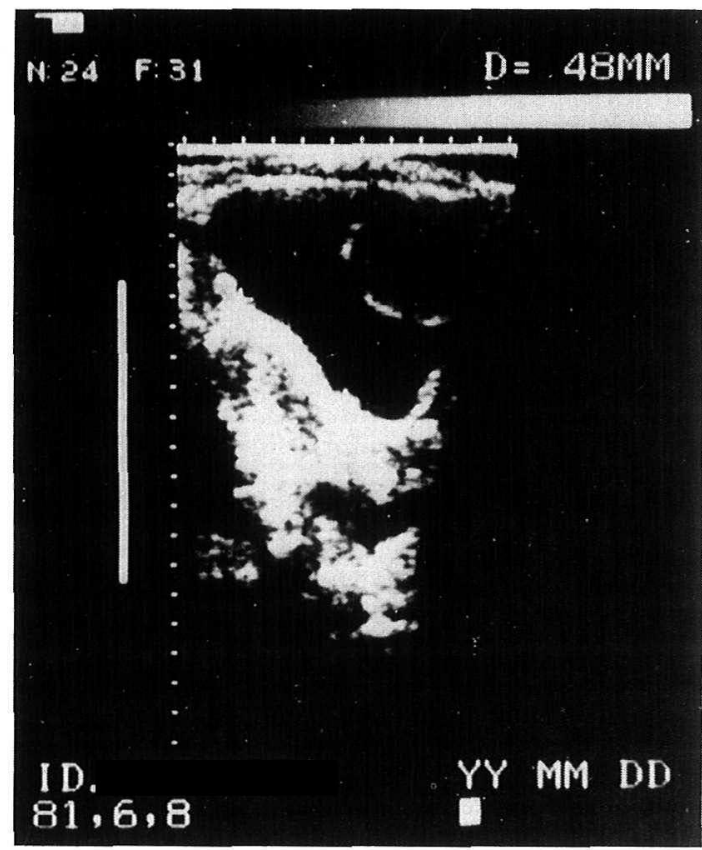

記載を見る。小児にみられるいわゆる膀脱ぶどう状肉 腫（Sarcoma botryoides）は肉眼的形態を主とした命 名であり，近年は胎児性横紋筋肉腫に統一する考克方 が一般的である6). 又組織的に光顕で横紋が確認でき ない場合でも電顕で Myofilament が確認でさるとの 報告もあり778), 今回の集計ではぶどう状肉腫は横紋筋 肉腫として分類した。

今回の集計でみると膀胱肉腫は横紋筋肉腫が64例 (48.1\%) と最も多く, 平滑筋肉腫 40 例 $(30.0 \%)$ を上 回つた。この両者之筋肉腫の 3 例を合わせると107例で 全体の 8 割をしめた。その外, 線維肉腫 7 例, 細網肉 腫 5 例，骨形成性肉腫 5 例などであつた（Table 2)。 文献的には McCrea and Post ${ }^{9}$ の膀脱肉腫288例の組 織細胞学的分類の詳細な報告があり,これでも Myogenic Sarcoma が多数をしめている。

2。性㐨よび年齢分布

男女比は, 膀脱肉腫全体では78対55で男性に多い。 横紋筋肉腫では41対23で男性が約倍で多いが，平滑筋 肉腫では20対20で差を認めなからた（Table 2)。文献 的にも横紋筋肉腫では男性に多い(10)11).

年齢分布は 5 齢以下と 30 齢以下から 60 歳に 2 つの ピークを認める。横紋筋肉腫では 45 例 $(70.3 \%)$ が 5 


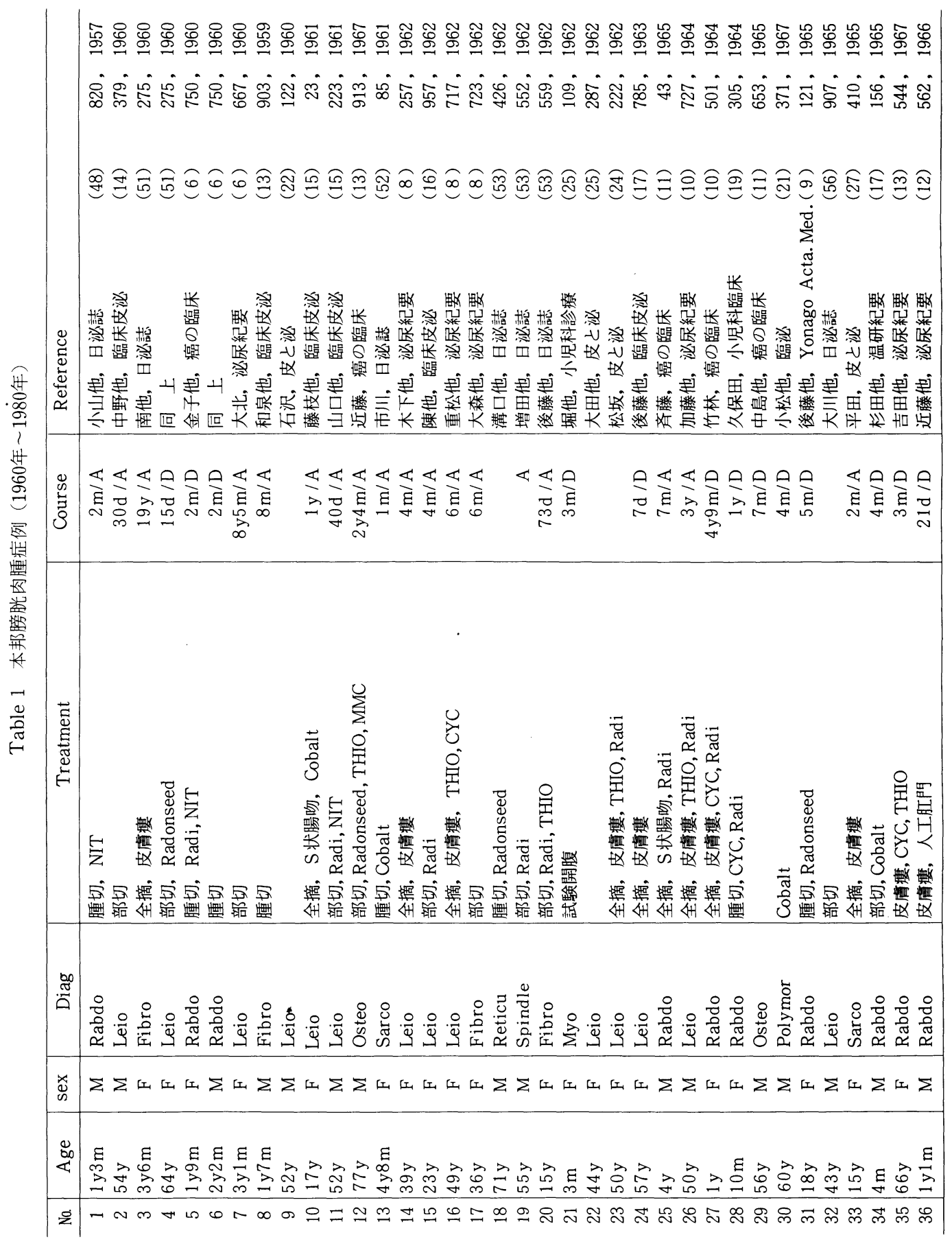




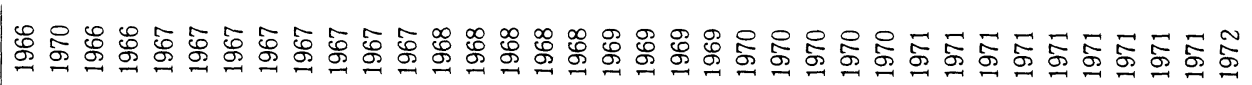

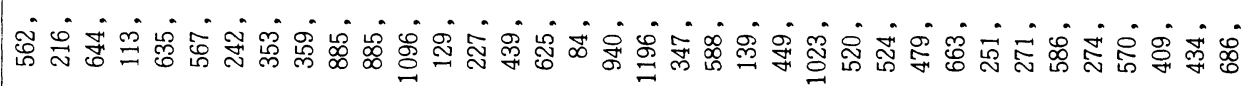

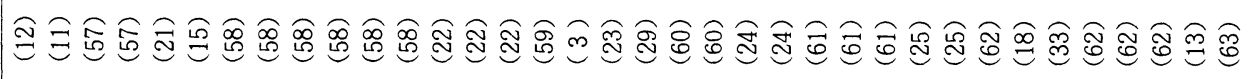

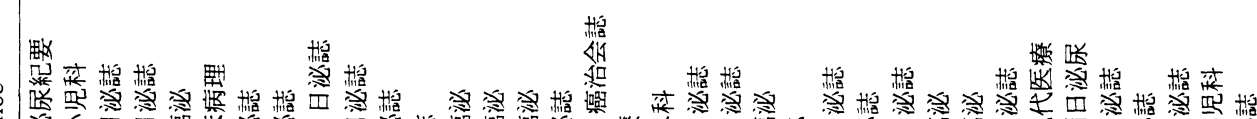

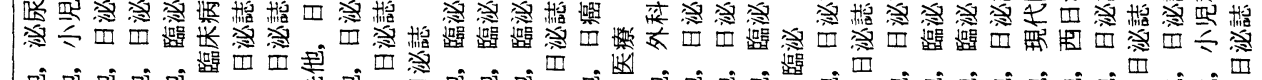

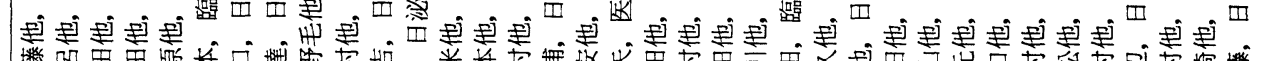

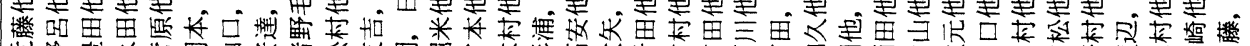

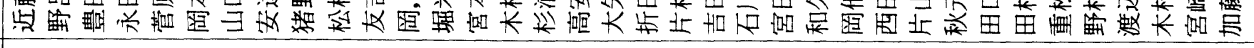

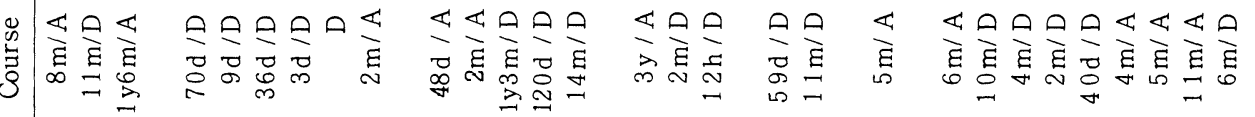

.

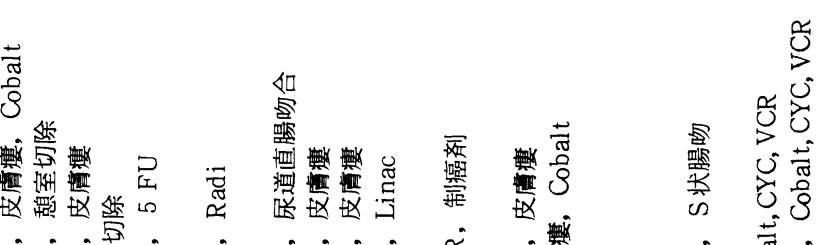

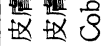

要

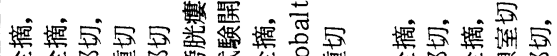

叫地地

两

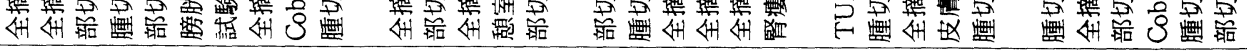

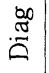

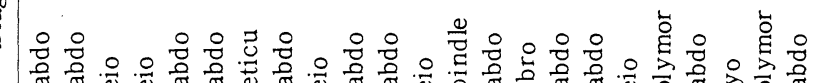

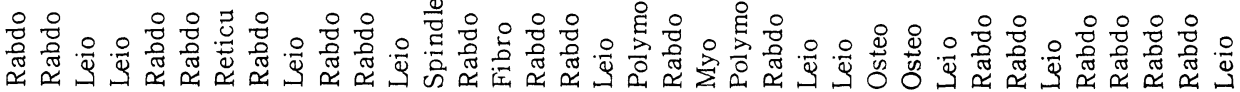

希

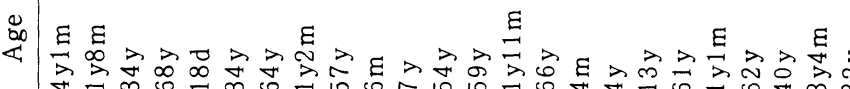

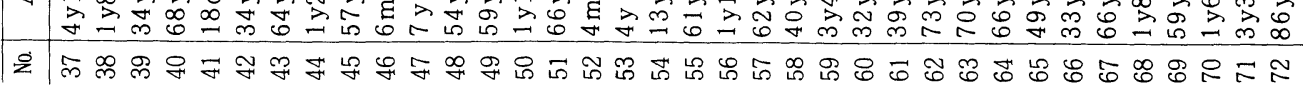




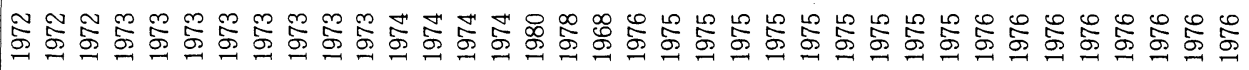

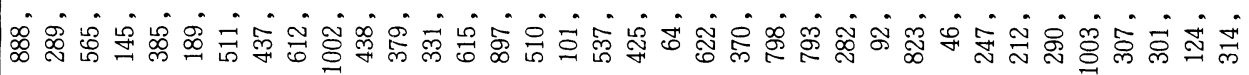

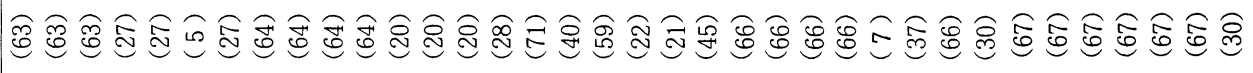
筷

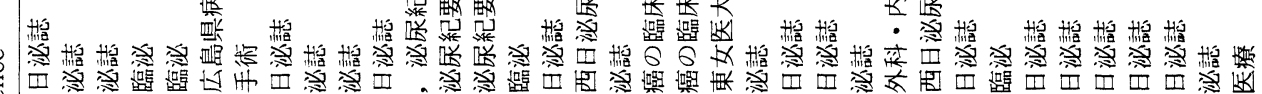

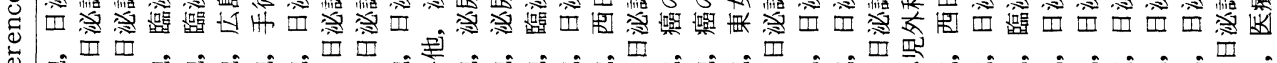

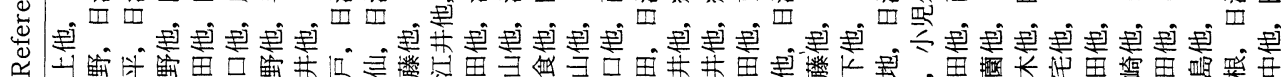

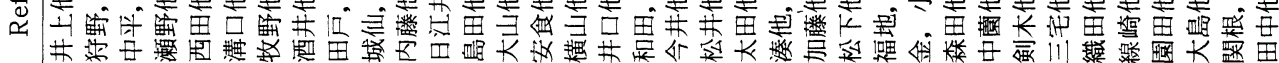

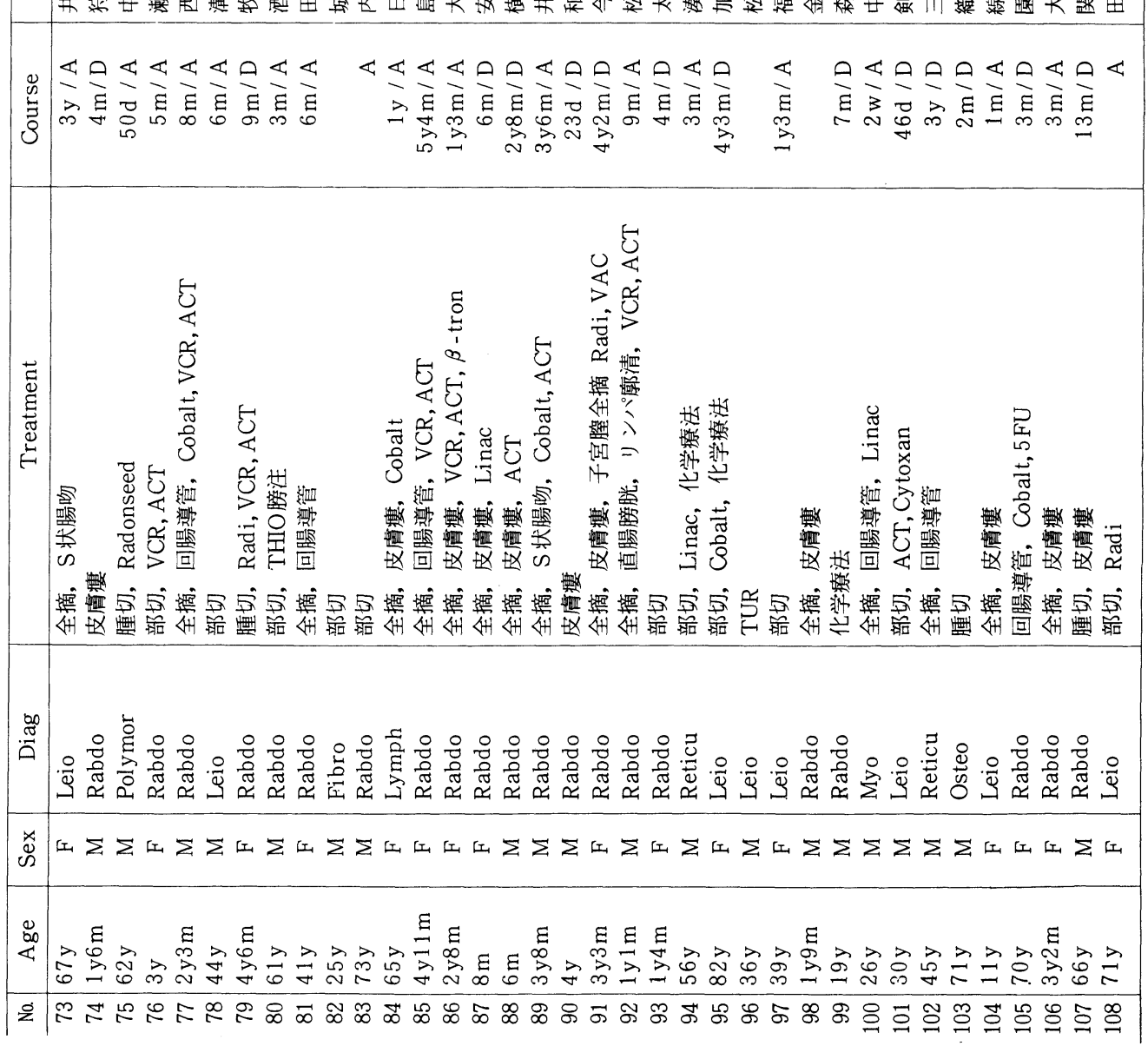




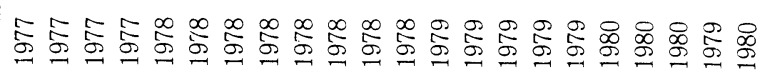

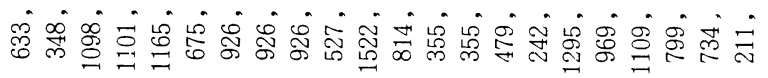

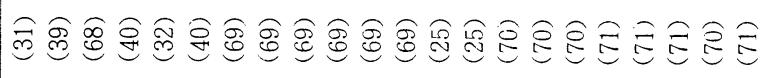

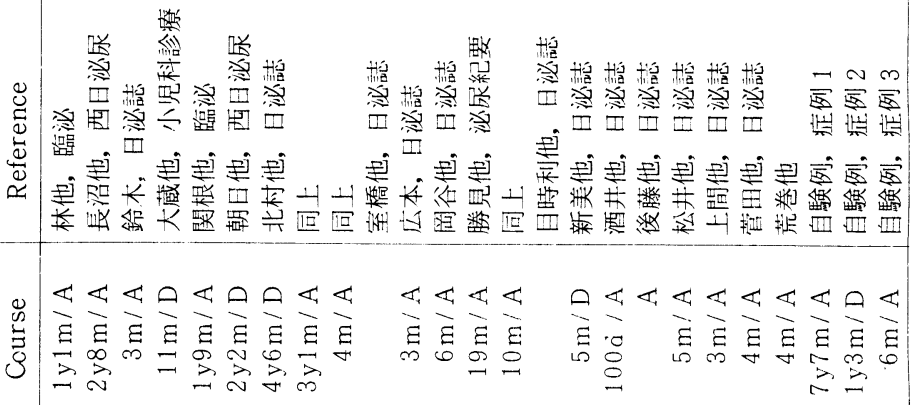

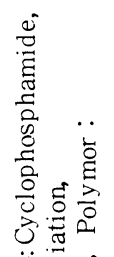
它焉贯 A票 它掏

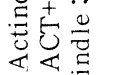
范贾 色势的 道

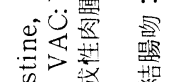

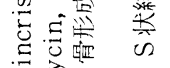
过高苍

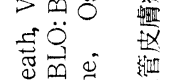

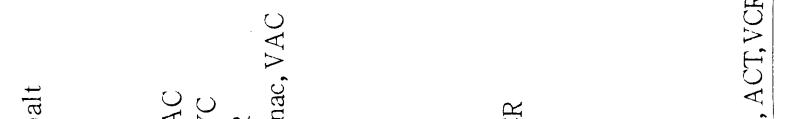


歳以下であるのに対し，平滑筋肉腫では38例（95\%） が10歳以上で特に 30 歳から 60 歳に多く, 両者に年齢分 布のあきらかな違いを認めた。 5 歳以上の横紋筋肉腫 はかなりあるが， 5 歳以下の平滑筋肉腫は僅か 1 例 ${ }^{22}$ （case 7, Table 1）にすぎなかつた。平均年齢は横紋 筋肉腫 12.3 歳, 平滑筋肉腫 45.7 歳, その他の肉腫 45.9 歳であつた（Fig. 8).

3. 症状

血尿が最も多く75例で半数以上にみられる。平滑筋 肉腫では血尿，頻尿，排尿痛などの膀脂炎様症状を主 訴とすることが多く, 横紋筋肉腫では排尿困難, 尿閉, 便秘など閉塞症状が多くみられ，又小児横紋筋肉腫で は腹部あるいは外陰部腫瘤を主訴とすることも多い

(Table 3).

\section{4. 発生部位}

横紋筋肉腫は䅡部，三角部に多く ${ }^{10)}$ 平滑筋肉腫は側 壁, 後壁に多(13114) といわれ，これが両者の鑑別点にな るともいわれるが，実際には腫瘍が大きく発生部位が 確定できないことも多い，今回の集計でみると，膀脱 肉腫全体では三角部が最も多く，従来少ないとされる 平滑筋肉腫症例もみられた。横絞筋肉腫はやはり頝部， 三角部に多くみられた（Table 4).

\section{5. 予後}

従来膀胱肉腫の予後はまつたく不良とされている。 しかしながら手術, 化学療法, 放射線療法の combination therapy の進歩により長期生存例や寛解例が増加 していることは，今回の集計にも現われている。本邦 報告例は残念ながら汪とんどが 1 年以内の観察例で, 今回の集計から予後を推定することは困難である。予 後の記載のあつた111例の報告時点での生死及び生存 期間を単純にまとめると Fig. 9 のごとくである．死亡 の明白なものは49例, その内訳は横絞筋肉腫33例で平 均生存期間 11.5 力月, 平滑筋肉腫 7 例で平均 10.8 力月, その他の肉腫 9 例で平均 6.8 力であつた。観察年数を 無視してみれば，横紋筋肉腫に死亡例が多い，しかし 多くの報告が 1 年以内の観察であり，平滑筋肉腫が横 紋筋肉腫より予後が良いとは断定できない，5年以上 生存例は, 術後 19 年の南等 ${ }^{5}$ の 線維肉腫 (Case 3, Table 1)を最長として，今回報告した症例 1 及び島田等 ${ }^{15) 16)}$ (Case 85, Table 1) の横紋筋肉腫 2 例と大北 ${ }^{12)}$ の平滑 筋肉腫 (Case 7, Table 1) 1 例の合計 4 例にすぎない. 2 年以上生存した，あるいはしている横絞筋肉腫は 9 例で，注とんどの症例が combination therapy をうけ ており，治療効果が予後に反映してきていると考兄ら
Table 2 本邦膀胱肉腫症例の組織分類および性差

\begin{tabular}{l|r|r|r}
\hline \multicolumn{1}{c|}{ 組織診断 } & \multicolumn{1}{c|}{ 男 } & \multicolumn{1}{c|}{ 女 } & 合計 \\
\hline 横紋筋肉腫 & 41 & 23 & 64 \\
平滑笳肉腫 & 20 & 20 & 40 \\
線維肉腫 & 4 & 3 & 7 \\
骨形成性肉腫 & 4 & 1 & 5 \\
細網肉腫 & 4 & 1 & 5 \\
多形性細胞肉腫 & 3 & 1 & 4 \\
紡鍾形細胞肉腫 & 1 & 1 & 2 \\
リンパ肉腫 & 0 & 1 & 1 \\
筋肉腫 & 1 & 2 & 3 \\
肉腫 & 0 & 2 & 2 \\
\hline \multicolumn{1}{c|}{ 合計 } & 78 & 55 & 133 \\
\hline
\end{tabular}

Fig. 8 本邦膀胱肉腫症例の年齢分布

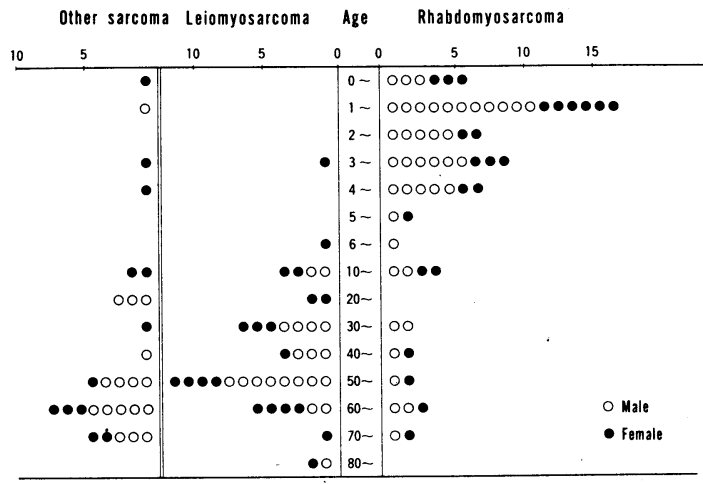

Fig. 9 予後記載のあつた本邦膀胼肉腫111例の報告 時点での生死および生存期間.

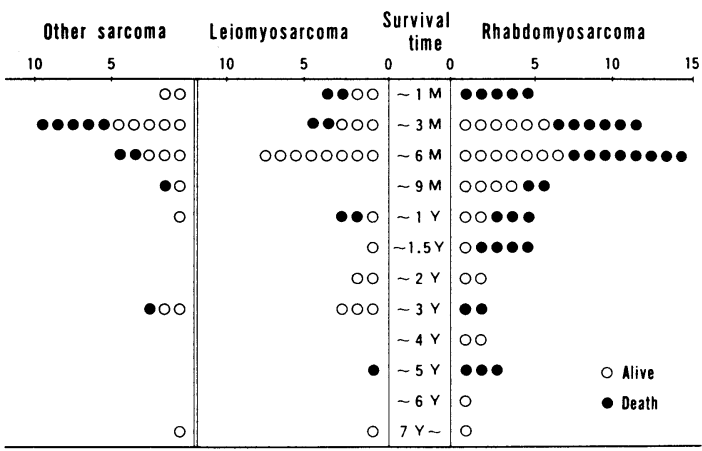

れ，今後更に予後の改善が期待される。

6. 治療

1961年 Pinkel and Pickren ${ }^{17)}$ が横紋筋肉腫に対し， 手術，化学療法，放射線療法の併用にて良好な治療効 果を報告して以来，数多くの併用療法報告がなされて 
Table 3 本邦膀脱肉腫症例の主訴

\begin{tabular}{l|c|c|c|c}
\hline \multicolumn{1}{c|}{ 主 訴 } & 横紋筋肉腫 & 平滑筋肉腫 & その他の肉腫 & 合計 \\
\hline 血尿 & 28 & 27 & 20 & 75 \\
排痛 & 18 & 16 & 8 & 42 \\
排㽷困難 & 26 & 1 & 7 & 34 \\
頻尿 & 14 & 11 & 8 & 33 \\
下腹部腫瘤 & 10 & 2 & 2 & 14 \\
尿閉 & 6 & 2 & 3 & 11 \\
便秘 & 6 & 1 & 0 & 7 \\
外陰部腫瘤 & 6 & 0 & 0 & 6 \\
下腹部痛 & 4 & 2 & 0 & 6 \\
尿失禁 & 1 & 2 & 1 & 4 \\
発熱 & 3 & 1 & 0 & 4 \\
その他 & 5 & 1 & 1 & 7 \\
\hline
\end{tabular}

いる．本邦でもこの10年間, 横絞筋肉腫例にはほとん どに，平滑筋肉腫や他の肉腫にも広く併用療法が施行 され，効果を上げている。

i）手術療法：膀胱肉腫に対する治療の基本は手術 療法である。今回の集計でみると約 9 割の症例になん らかの手術療法がなされて招り，その内訳は膀脱全摘 出術 54 例 (40.6\%), 膀胱部分切除術35例 (26.3\%), 腫瘍切除術17例（12.8\%）などである（Table 5)。横 紋筋肉腫症例では32例 $(50 \%)$ に膀胼全摘出術がなさ 机ており，2 年以上生存例 9 例 (Case $27^{18)}, 85^{15)}, 88^{19)}$, $89^{20)}, 91^{111}, 114^{21)}, 115^{22)}, 116^{22)}$ Table 1) をみても全例 に膀胼全摘出術がなされている. Auvert ${ }^{23)}$, Teff $^{24)}$, Mackenzie $^{25 / 26)}$ ，北村等 ${ }^{22)}$ が述べているごとく早期の 膀脱全摘出術あるいは拡大膀脱全摘出術が膀脱横紋筋 肉腫の手術療法の基本と考えられる。これに対し平滑 筋肉腫では16例 (40\%) に膀脱部分切除術がなされて 抢り, 膀胱全摘出術13例を上迴つている. Mackenzie ${ }^{25)}$ は膀胱平滑筋肉腫で 3 年以上生存例 11 例のうち 8 例が 膀胱部分切除術例であつたと述べている. 又 Tara ${ }^{27)}$ は文献上 5 年以上生存の膀脱平滑筋肉腫 7 例を集め, その内 6 例が膀脱部分切除術例であつたと述べてい る。たしかに腫瘍が単発で，三角部や膀胱䅡部から遠 く, 大きくない場合は膀胱部分切除が可能と思われ， 又逆にこのような膀胼平滑筋肉腫は予後が良いとも考 光られる.今回の集計では長期予後観察例が少ないが, Case $7^{12)}$, Case $54^{28)}$ (Table 1) のごとく膀胼部分切 除術で 3 年以上生存している症例がみられた。しかし 平滑筋肉腫でも膀胱全摘出術を選択すべき症例も多い 之思われ，我々の症例 3 子腫瘍が大きく膀胱䅡部への 広がりをみたため膀胱全摘出術を施行した。
Table 4 本邦膀胼肉腫の発生部位

\begin{tabular}{l|c|c|c|c}
\hline 部位 & 横紋筋肉腫 & 平滑筋肉腫 & その他の肉腫 & 合計 \\
\hline 三角部 & 15 & 9 & 6 & 30 \\
頸部 & 15 & 6 & 1 & 22 \\
頂部 & 3 & 9 & 6 & 18 \\
側墜 & 9 & 12 & 5 & 26 \\
後壁 & 5 & 8 & 3 & 16 \\
前壁 & 3 & 1 & 1 & 5 \\
不明 & 25 & 10 & 12 & 47 \\
\hline
\end{tabular}

尿路変向をみると, 尿管皮膚瘦 39 例と最も多く, 回 腸導管12例，尿管 S 状腸吻合術 9 例などであつた (Table 5). 北村等 ${ }^{22)}$ は小児横紋筋肉腫では, 再発を考 觉てまず尿管皮膚瘦を造設し，5年経過後に Tumor free 確認後に回腸導管を抗こなうと述べている. 我々の症例では, 最初から回腸導管を造設した。症例 1 は経過良好であるが，症例 2 は再発し末期には回腸 導管の Stoma よりの腫瘍突出を認めた。

膀胼肉腫の手術療法の基本は，より早期の膀胱全摘 出術であると我々は考学る。

ii）放射線療法：今回の集計でみると46例（34.6\%） になんらかの放射線療法がはされているが, その効果, 予後との関係は判定不能であつた。 小児横紋筋肉腫で は化学療法との併用で放射線療法の効果は認められて 抢り ${ }^{24) 29)}$ ，我々の症例 $2 ， 3$ も深部照射を併用してい る. 症例 2 は放射線療法と Actinomycin D にて一時的 ではあつたが，腹部腫瘤の著明な縮少を認めた。

iii）化学療法：小児横紋筋肉腫に対する手術, 放射 線との併用で, Vincristine, Actinomycin D, Cyclophosphamide あるいはAdriamycin を使用し，すぐれ た効果を Grosfeld ${ }^{30)}$, Clatworthy ${ }^{31)}$, Heyn ${ }^{32)}$, Pratt ${ }^{33)}$, 
Table 5 本邦膀脱肉腫症例の手術療法

\begin{tabular}{l|c|c|c|c}
\hline \multicolumn{1}{c|}{ 手 術 } & 横紋筋肉腫 & 平滑筋肉腫 & その他の肉腫 & 合計 \\
\hline 膀胱全摘出術 & 32 & 14 & 8 & 54 \\
膀胱部分切除術 & 10 & 16 & 9 & 35 \\
腫啺切除術 & 6 & 2 & 9 & 17 \\
尿路変向のみ & 8 & 1 & 0 & 9 \\
T.U.R. & 0 & 2 & 0 & 2 \\
手術不能 & 5 & 1 & 2 & 8 \\
不明 & 3 & 4 & 1 & 8 \\
\hline
\end{tabular}

\begin{tabular}{l|r|r|r|r} 
尿路変向法 \\
\hline 尿管皮膚瘦 & 21 & 11 & 6 & 39 \\
回腸導管 & 8 & 2 & 2 & 12 \\
尿管 S 状結腸吻合 & 7 & 2 & 0 & 9 \\
その他 & 3 & 0 & 0 & 3 \\
\hline
\end{tabular}

Table 6 本邦膀胱肉腫症例の放射線療法抢よび化学療法

\begin{tabular}{l|c|c|c|c}
\hline & 横紋筋肉腫 & 平滑筋肉腫 & その他の肉腫 & 合計 \\
\hline 放射線療法 & 20 & 16 & 10 & 46 \\
化学療法 & 31 & 11 & 5 & 47 \\
\hline Vincristine & 19 & 6 & 1 & 26 \\
Actinomycine D & 19 & 4 & 2 & 25 \\
Cyclophosphamide & 12 & 4 & 1 & 17 \\
Thio-TEPA & 1 & 3 & 2 & 6 \\
Adriamycin & 3 & 0 & 0 & 3 \\
MMC & 0 & 2 & 1 & 3 \\
5-FU & 2 & 1 & 0 & 3 \\
Others & 3 & 4 & 1 & 8 \\
Vin.+Act. +Cyclo. & 4 & 2 & 0 & 6 \\
Vin.+ Act. & 10 & 2 & 1 & 13 \\
Vin. +Cyclo. & 4 & 1 & 0 & 5 \\
\hline
\end{tabular}

Ghavimi $^{34) 35)}$ ，Maurer ${ }^{36)}$ 等が報告し，本邦でも勝見 等 ${ }^{16)}$ の報告など数多くみられる. 今回の集計でみると, Vincristine, Actinomycin D, Cyclophosphamide が多 く使われて打り，特にVincristine, Actinomycin D の 併用例が多かつた（Table 6). 横紋筋肉腫では，2 年 以上生存した 9 例中 8 例に Vincristine, Actinomycin D, Cyclophosphamideの併用あるいはいずれかの薬 剂が使用されている。又この V.A.C. 療法が本邦で多 くなされるようになつた1970年以後の方が，小児横紋 筋肉腫の生存期間は延びており, 化学療法の延命効果 は，はつきりと表われている。しかしながら根治とい

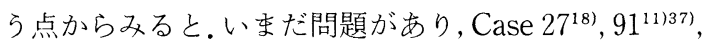
$115^{22)}$ (Table 1) のごとく, 術後 4 年以上経過しての

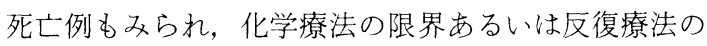
さずかしさを物語つていると思われる。

膀腃平滑筋肉腫に対する化学療法には，まつたく定
説がなく，その効果も不明であるが，横紋筋肉腫に準 じて Vincristine, Actinomycin D, Cyclophosphamide が使用されている例が多い.今後膀胱平滑筋肉腫に対 して, 長期予後観察とともに, 化学療法の効果を確立 する必要があると考学られる。

\section{結語}

2 例の小児膀胱横紋筋肉腫之 1 例の成人膀胼平滑筋 肉腫症例を報告した。横紋筋肉腫例の 1 例は，5歳男 子で膀脱全摘出術後 7 年 7 力 月つた現在健在であ り, 他の 1 例は，3歳男子で膀脱全摘出術後に化学療 法, 放射線療法を施行したが 1 年 3 力月後死亡した。 膀胼平滑筋肉腫例は, 膀胱全摘出術, 併用療法施行し 術後 6 ケ月の現在健在である.

1960年から1980年までの本邦膀胱肉腫133例を集計 した。

1. 横紋筋肉腫 64 例, 平滑筋肉腫 40 例, その他の肉腫 
29例であつた。

2、性差は横紋笳肉腫で男に多く, 平滑筋肉腫で男女 同数であつた。年齢は横紋筋肉腫では70\%が 5 歳以下 であり, 平滑筋肉腫では $95 \%$ が10歳以上であつた。

3. 症状は血尿が最も多く, 横紋筇肉腫では閉塞症 状，平滑筋肉腫では膀脱炎様症状が多かつた。

4. 発生部位は横紋筋肉腫で頚部, 三角部に多く, 平 滑筋肉腫で頂部，側壁に多かつた。

5. 症例報告が大部分を占めているため観察期間が 短かく, 予後の推定は困難であり, 予後不良の疾患と いわれているものの， 5 年以上生存の明らかなものが 4 例又られた。

6. 治療は, 横紋筋肉腫の $50 \%$ に膀脱全摘出術がなさ れ，平滑筋肉腫では $40 \%$ に膀胱部分切除術がなされて いる。坚横紋筋肉腫には手術, 放射線療法に, Vincristine, Actinomycin D, Cyclophoshamide の化学療 法が多く施行されていた。

本論文の要旨は1981年 9 月26日開催された第133回日本 泌尿器科学会東海地方会に扔いて発表した。

\section{文献}

1) Dean, A.L., Mostofi, F.K., Thomson, R.V. and Clark, M.L.: A restudy of the first fourteen hundred tumors in the bladder tumor registry armed factors institute of pathology. J. Urol., $71: 571-590,1954$.

2) Thompson, I.M. and Coppridge, A.J.: Bladder sarcoma. J. Urol., 82: 329-332, 1959.

3) 辻一郎：膀胱癌の病理組織学. 日泌尿会誌, 45 : 226-228, 1950.

4）市川篤二：膀胖腫瘍の遠隔成績調查. 日泌尿会誌, $49: 602-610,1958$.

5）南武, 安藤, 弘, 舘 英一, 福島 孝, 伊藤芳 雄, 志賀宗雄: 膀胱肉腫症例附幼児膀胼全剔治験 例. 日泌尿会誌，51：275-288，1960.

6) Horn, R.C. and Enterline, H.T.: Rhabdomynsarcoma; A clinicopathological study and classification of 39 cases. Cancer, 11: 181-199, 1958.

7) 吉田 修, 岡田謙一郎, 桐山旁夫 : 原発性膀胱横紋 筋肉腫の 1 剖検例. 泌尿紀要, $13: 544-547,1967$.

8）関根英明, 吉川謙一郎, 横川正之, 青木 望, 川原 稑, 宮本博泰：小児膀胱紋笳肉腫の 1 例. 特にその 光顕および電顕像について. 臨泌, 32 : 1165-1168, 1978.

9) McCrea, L.E. and Post, E.A. : Sarcoma of the bladder. Urol. Surv., 5 : 307-356, 1955.

10) Legier, J.F.: Botryoid sarcoma and rhabdomyosarcoma of the bladder: Review of the literature and report of 3 cases. J. Urol., 86 : 583-590, 1961.

11）今井克忠, 鈴木麒一, 沼沢和夫：小児の膀胱に原発 した横紋筋肉腫の一例. 癌の臨床, $22 ： 425-431$, 1976.

12) 大北健逸：小坚膀脂平滑筋肉腫. 術後8年尚健在な 女児の 1 例。泌尿紀要, 6:667-671，1960。

13）木下勝博, 系井壮三, 河西 稔：膀朕平滑筋肉腫の 1 例. 泌尿紀要, 8：257-261，1962.

14) Silbar, J.D. and Silbar, S.J. : Leiomyosarcoma of bladder: Three case reports and a review of literature. J. Urol., 73 : 103-111, 1955.

15）島田宏一郎, 福島克治, 酒井 晃：膀胱ブドウ状内 腫の 1 例. 泌尿紀要, $20: 331-334,1974$.

16）勝見哲郎, 長野賢一, 久住治男, 黒田恭一：小児に おける膀羘および前立腺横紋筋肉腫の治療経験。 泌尿紀要, 25：355-361，1979.

17) Pinkel, D. and Pickren, J.: Rhabdomyosarcoma in children. J.A.M.A., $175: 105-110$, 1961.

18）竹林茂夫, 石津俊一, 田中 普, 橋口剛志：幼小児 の会陰部に見られる葡萄肉腫 (中肧葉性混合腫瘍) について. 癌の臨床, 10:501-509, 1964.

19）横山博美, 広瀬欽次郎, 今尾貞夫, 新妻雅治, 早川 恵子, 宮腰達郎, 青木幹雄 : von Recklinghvse 氏 病に膀胼葡萄状肉腫の併発せる乳児例 2 例. 日泌 尿会誌, $71: 510,1980$.

20）井口琇吉, 藤井 浩, 浅野聡平: 幼児膀胱横紋笳肉 腫の 1 例. 西日泌尿, 40:101-106, 1978.

21）朝日俊彦, 平野 学, 吉本 純, 大森弘之, 松村陽 右, 岡本 司: 小児膀脱横紋筋肉腫症例に対する 治療。西日泌尿, 40：675-680，1978.

22）北村唯一, 杮澤至恕, 大田黒和生, 秋山 洋, 田口 信行, 小出 亮, 清水興一：小児下部尿路性器横紋 筋肉腫の 5 例. 日泌尿会誌, $69 ： 926-934,1978$.

23) Auvert, J., Boureau,M. and Weisgerber, G. : Embryonal sarcoma of the lower urinary tract in children: 5-year survival in 2 cases after radical treatment. J. Urol., 112 : 396-401, 1974.

24) Tefft, M. and Jaffe, N.: Sarcoma of the bladder and prostate in children. Cancer, 32 : 1161-1177, 1973.

25) Mackenzie, A.R., Whitmore, W.F. and Melamed, M.R. : Myosarcomas of the bladder and prostate. Cancer, $22: 883-844,1968$.

26) Mackenzie, A.R., Sharma, T.C., Whitmore, W. F. and Melamed, M.R. : Non-extirpative treatment of myosarcomas of the bladder and prostate. Cancer, $28: 329-334,1971$.

27) Tara, H.H. and Mentus, N.L.: Leiomyosarcoma of urinary bladder. Urology, $2: 460-462$, 1973 . 
28）大矢正己，土肥英雄：小児膀脱腫瘍 (平滑笳肉腫) の 1 例. 医療, 23：940-944，1969.

29) Nerson, A.J.: Embryonal rhabdomyosarcoma : Report of twenty-four case and study of the effectiveness of radiation therapy upon the primary tumor. Cancer, $22: 64-68,1968$.

30) Grosferd, J.L., Clathworthy, H.W. Jr. and Newton, W.A. Jr. : Combined therapy in childhood rhabdomyosarcoma: An analysis of 42 cases. J. Pediat. Surg., 4:637-645, 1969.

31) Clatworthy, H.W. Jr., Braren, V. and Smith, J. P.: Surgery of bladder and prostatic neoplasmas in children. Cancer, 32: 1157-1160, 1973.

32) Heyn, R.M., Holland, R., Newton, W.A., Tefft, M., Breslow, N. and Hartmann, J.R. : The role of combined chemotherapy in the treatment of rhabdomyosarcoma in children. Cancer, 34 : 2128-2142, 1974.

33) Pratt, C.B., Hustu, H.O., Fleming, I.D. and Pinkel, D.: Coordinated treatment of childhood rhabdomyosarcoma with surgery, radiotherapy and combination chemotherapy. Cancer Research, 32:606-610, 1972 .
34) Ghavimi, F., Exelby, P.R., D'Angio, G.J., Whitmore, W.F.Jr., Lieberman, P.H., Lewis, J.L.Jr., Mike, V. and Murphy, M.L.: Combination therapy of urogenital embryonal rhabdomyosarcoma in children. Cancer, 32 : 1178-1185, 1973.

35) Ghavimi, F., Exelby, P.R., D'Angio G.J., Cham, W., Lieberman, P.H., Tan, C., Mike, V. and Murphy, M.L. : Multidisciplinary treatment of embryonal rhabdomyosarcoma in children. Cancer, 35:677-686, 1975.

36) Maurer, H.M., Moon, T., Donaldson,M., Fernandez, C., Gehan, E.A., Hammond, D., Hays, D. M., Lawrence, W.Jr., Newton, W., Ragab, A., Raney, B., Soule, E.H., Sutow, W.W. and Tefft, M.: The intergroup rhabdomyosarcoma study: A preliminary report. Cancer, 40 : 2015-2026, 1977.

37）今井克忠, 星 宣次, 原田一哉, 松下昌人, 小津堅 輔, 杉田篤生, 木村伯子, 小態司郎：小児膀胱横紋 筋肉腫症例の 1 剖検例. 日泌尿会誌, $70: 261$, 1979 .

（1982年1月23日受付） 